\title{
Bratislava and the Planned River: Mapping the Impact of the Danube Regulations between 1772 and 1896 on Urban Development
}

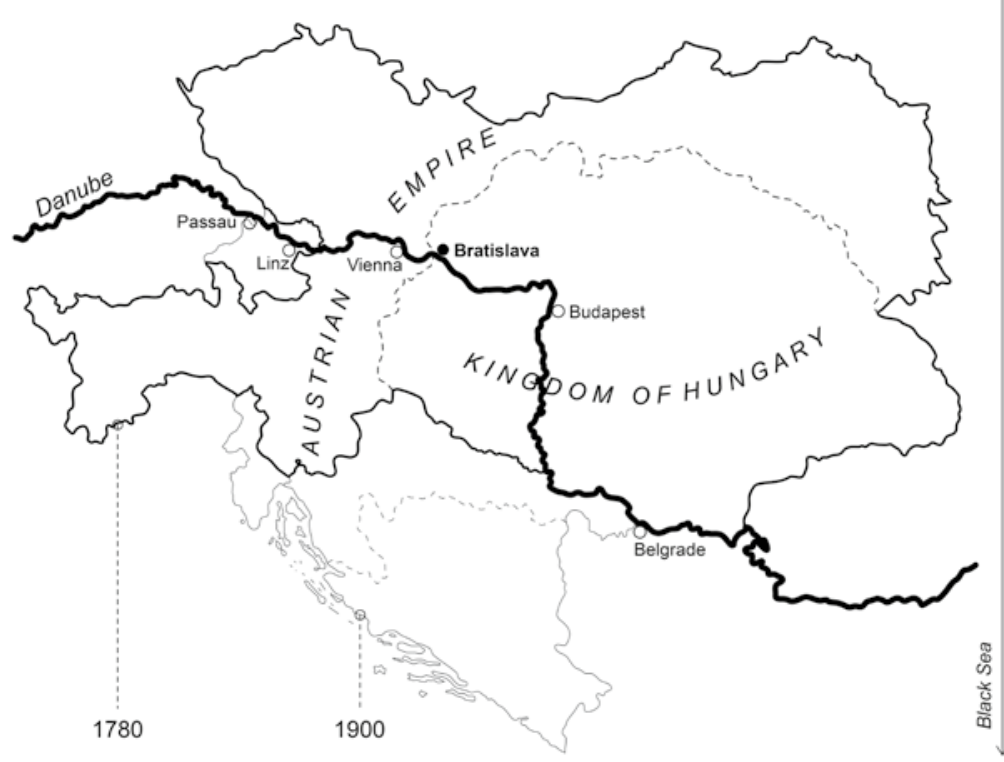

Bratislava a plánovaná rieka:

Mapovanie vplyvu regulácií

Dunaja v rokoch 1772 až 1896

na rozvoj mesta

Monika Bočková

Rieka Dunaj je zvyčajne ponímaná viac ako prírodný element, než ako spoločenský produkt. Jeho skúmanie dlhodobo spadá do odborov fyzickej geografie, fluviálnej geomorfológie, hydrológie a ekológie. Súčasná podoba Dunaja nie je len výsledkom prirodzeného vývoja jeho toku, no najmä zámernej ludskej činnosti. V priebehu storočí bol Dunaj z viacerých dôvodov cielene formovaný, zužovaný či rozširovaný, narovnávaný, usmernený a prehradený.

Predmetom prebiehajúceho výskumu sú také historické transformácie rieky, ktoré priamo či nepriamo ovplyvnili štruktúru mesta Bratislava. Skúmanie premien Dunaja z pohladu urbanizmu umožňuje nový naratív urbánnych dejín s dôrazom na prítomnost' rieky. L’udské zásahy do Dunaja vždy vyplývali z konkrétnych potrieb, ako napríklad splavnenie rieky, prispôsobenie koryta na parou poháňanú dopravu či protipovodňová ochrana. Výskum je orientovaný na skúmanie časových úsekov regulovania rieky, jej industrializácie a urbanizácie bývalých záplavových území. V doterajšom skúmaní sme sa zaoberali obdobím troch hlavných regulácií pozorovaného úseku rieky, ktoré prebehli v rokoch 1772 až 1896.

Dunaj vinúci sa vtedajšou habsburskou monarchiou prepájal ríšu od horného Rakúska až po dolné Mad’arsko, prechádzajúc cez jej najdôležitejšie administratívne sídla - Viedeň, Bratislavu a Budapešt'. Monarchia bola zložená z rôzne rozvinutých častí, či už z hladiska industrializácie alebo urbanizácie, nehovoriac o samotnej etnickej rozmanitosti. Vd’aka rieke a jej prítokom bolo možné spojit' jednotlivé časti ríše do jednej obchodnej a kultúrnej siete.

Mestská štruktúra Bratislavy sa historicky formovala na l'avom brehu Dunaja, a na začiatku skúmaného obdobia s ním nemala priamy kontakt. Už po prvej regulácii, ked' bol zvýšený násyp dôležitej Viedenskej cesty, bol založený verejný park na pravom brehu. Počas 19. storočia sa z brehu postupne stalo nábrežie vd’aka druhej regulácii, ktorá bola zameraná na stabilizáciu toku. Výsledkom tretej regulácie bola podoba rieky, ako ju z vel'kej časti poznáme dnes. Eliminácia bočných ramien Dunaja viedla k vysúšaniu inundačných území, kde bolo možné neskôr orientovat' novú 
výstavbu Dunajskej a továrenskej štvrte. Výstavba prvého stáleho mostu cez Dunaj zároveň otvorila cestu myšlienkam rozvoja mesta na druhej strane rieky.

V snahe analyzovat' rieku ako prírodný a súčasne človekom pretvorený fenomén bolo žiaduce zvolit hybridnú metódu skúmania. Vybrané aspekty historiografického bádania boli priamo interpretované na podklade historických máp vo forme mappingu. Mapping je, na rozdiel od mapy, nekonvenčným zobrazením územia, ktoré umožňuje vnímat' nové súvislosti. Priestorové javy boli v tomto prípade obohatené o časovú os klúčových udalostí.

Mapping zároveň zobrazuje skúmaný jav v kontexte rôznych mierok, od tzv. dunajskej monarchie cez územie dnešnej Bratislavy až po centrálnu čast' mesta. Vd’aka použitej metóde sa jasne ukazuje, že lokálne zásahy do rieky boli z vel'kej časti súčastou nadnárodnej vízie splavnenia Dunaja v Rakúsko-Uhorsku. Je teda možné konštatovat', že celostné regulácie Dunaja umožnili vznik mestských priestorov a štvrtí, ktoré dodnes definujú obraz Bratislavy.

Hoci regulácie Dunaja viedli k vytvoreniu tepny lodnej dopravy, spätne bývajú hodnotené z pohladu negatívnych zásahov do životného prostredia. Bratislava prišla o územia vzácnej krajiny a tie, ktoré pri rieke zotrvali, sú podrobované neustálym tlakom urbanizácie. Prebiehajúci výskum preto môže byt' príspevkom k aktuálnej debate o budúcnosti pozostatkov lužných lesov či prípadnom obnovení zaniknutých riečnych ramien.

\section{River-City Research}

The Danube river in Bratislava is regarded mostly as a natural rather than cultural entity, and accordingly its examination has been the subject of physical geography, fluvial geomorphology, hydrology and ecology. However, the Danube, like the majority of rivers, is an entanglement of nature and culture. ${ }^{1}$ The current pattern of the Danube as urban river is not only the result of its natural channel's evolution but also of human intentional modification. Over the centuries, the Danube has been artificially shaped - narrowed, channelled, straightened, dammed, and embanked. Therefore, the river can be analysed as an agency in the development of the city, one that both shapes and is shaped by the city.

The aim of the ongoing research project is to look at such riverine transformations that have directly influenced the structure of the city. This river-centric approach thus provides a new perspective on the formation of Bratislava and considers the transformations of the river from the urban planning point of view. Human interventions in its flow have been based on specific needs, such as river channelization, adaptation to steam power transport and flood protection. These interventions enabled the use of the river for recreation and led to the drying of floodplain areas, where it was later possible to situate new construction.

Similarly oriented contributions were recently published in the volume River Cities, City Rivers (2019)3), presenting various case studies on the dual character of the river-city relation. The study of urban history in relation to environmental history has recently emerged as a major topic. A comprehensive study on Vienna and the Danube published as Wasser Stadt Wien (2019) ${ }^{4}$ integrates knowledge from the social sciences into the examination of natural processes and human interventions into the Danube River.

The Bratislava section of the Danube is a long-term object of interest for naturalists. The most important findings about the morphological changes of the Danube River have been provided by Petr Pišút's extensive research, examining the issue from the point of view of fluvial geomorphology. In the field of urban history, the topic of urban spaces along the river was partially covered in the research project Bratislava (Un) Planned City (2020), ${ }^{5}$ which served as the conceptual basis for the presented paper. The objective of the research was the formation of Bratislava during the 2oth century, realised both in a planned and unplanned manner. Within the selected urban situations, those directly affected by the Danube River were found to be the left embankment, the industrial district on the left bank and the Danube District (Dunajská štvrt').

The paper deals with the period of the three main regulations of the Danube, ranging between the first initiatives in 1772 to the end of the regulatory works in 1896 . These arrangements preceded the emergence of the aforementioned urban situations that can be observed on the banks of the river today.

\section{Mapping as an Analytical Tool}

In order to observe the river as both a natural and cultural element, and to analyse the formative impact of Danube channelization, a hybrid method needed to be engendered. The combination of historiographical research and the visualisation of space-related information resulted in the idea of mapping. While research in the field of urban history is mostly accompanied by historical maps in their original form, mapping, on the other hand, is a practice that brings wider possibilities of depicting territory to monitor a selected phenomenon. Unlike conventional maps, mapping does not only interpret the observed phenomenon but it allows for incorporation of all relevant aspects to find new contexts that would not otherwise be visible.

The basis for visual information for this contribution was the collection of maps from the first, second and third military survey of the Habsburg Empire combined with maps of planned regulations. By deforming, layering, and comparing city depictions from different periods, it was possible to distinguish specific transformations on a relevant scale and highlight the selected arrangements, whether constructed or planned. To ensure that the mapping forms a representation of the process over time, a timeline of historical events was included. 
Regulations took place as an integral part of the transnational vision of river channelization as a step towards its navigability. Therefore, even the large-scale context of these operations is important to understand the motives and local impacts of city-scale regulations. This vantage point brings to the topic a different light than only a local case study would. The inclusion of the geopolitical context helps to understand the motivations of the main actors and to trace the individual administrations established to fulfill the goal.

\section{City by the River}

The history of the first settlements on the territory of today's Bratislava is linked to the Danube, although the city was founded by the river and not directly on it. The Danube was enclosed by the rocks of the Devín Gate, but then divided into several branches creating vast marshes. Consequently, a favorable location was offered by the adjacent, higher river terraces covered by gravel, formed on the left bank by the fluvial erosion. The castle hill above the Danube strategically controlled a wide territory including the settlement at the crossing of two important trans-European trade routes. While the steep cliffs of the Lesser Carpathians protected the city from the north and west, the branched riverine system provided protection from the south. ${ }^{6}$

During medieval times, the Danube already served as a significant transport axis fulfilling the definition of a flow described by theorist Ignasi de Solà-Morales as "the continuous movement of people, goods, services and data".7 Hidden behind the fortification walls, the city benefited from its proximity to the river thanks to the ports where tolls were collected. In addition to the migration of commodities and people, the Danube also ensured supplies of raw materials: fishing provided a livelihood and goods to trade while the floodplain forests were a source of timber.

No suburbs were built on the right bank of the Danube, nor were there any permanent bridges over the river. Several river crossings developed in the vicinity of Bratislava - depending on the water flow in the Danube, they were either fords or ferries. The city respected its natural border defined by the stream and its expansion was oriented mainly to the northeast, along the Carpathian access roads that led to the ford.

In the period of the 18th century, the Danube in Bratislava was characterised by two major parallel channels - the dominant Croatian Channel (Chorvátske rameno, then the Carlburger Arm) and the navigable central channel (Grosse Donau). The river's flow was unstable due to its shallows, winding paths and its tendency to flood in the spring and fall and to freeze during winter. The small channels together with dozens of islands created conditions for the formation of ice barriers and the following spring floods with disastrous effect.

\section{The Imperial River}

At the beginning of the 18th century, the Danube traversed the entire Habsburg Monarchy, leading to its secondary designation as the Danube Monarchy. From the Bavarian city of Passau, the Danube entered the territory of Upper Austria on the western border. Crossing the main administrative cities - Vienna, Bratislava (Pressburg/Pozsony) and the then not yet united Buda and Pest, the river continued to Lower Hungary, all the way to the monarchy's southern border near the Serbian capitol Belgrade. The monarchy was composed of differently developed parts regarding the level of their industrialization and urbanization, not to mention the ethnic diversity itself. Thanks to the river and its tributaries, it was possible to connect individual parts of the empire into one commercial and cultural network.

The importance and potential of the Danube as a waterway was also understood by Empress Maria Theresa. As a part of her numerous enlightenment reforms, she urged the improvement of navigation and commerce along the Danube. This endeavour, likewise fostered by all of her successors, transformed the riverscapes in the entire monarchy. After all, the secondary goal of the emperors was to display a powerful dynasty capable of constructing such ambitious projects. ${ }^{8}$ To begin the channelization of the Danube, as her first major initiative Maria Theresa established the Navigation Directorate in 1771 and commissioned it to map the Upper and Middle Danube ${ }^{9}$ with its tributaries under the guidance of Navigation Director Joseph Walcher.

Bratislava at the time was still the capital and coronation city of Hungary, as a result of the occupation of Hungary by the Ottoman Empire. Additionally, the city was a political centre of the monarchy hosting the two most important Hungarian central offices - the Royal Hungarian Governor's Council and the Royal Hungarian Chamber. Bratislava clearly benefited from the increased importance. The presence of central offices, the permanent seat of the governor and the frequent visits of the rulers had an impact on the development of the city. In sixty years, its population more than tripled: while in 1720 there were about 9000 inhabitants in the city, the census from 1787 resulted with 28707 inhabitants. ${ }^{10}$

The main connection between Vienna and Bratislava was in that time enabled by the Vienna Road (Via Viennensis) stretching along the right bank of the Danube. The road led through a former island (Brücken $\mathrm{Au}$ ) and continued via a ferry called the "flying bridge" (Fliegende Brücke). This alluvial area was exposed to soil erosion and the flooding had previously been controlled only in an inefficient manner. Every time the water level of Danube rose, it was necessary to bypass the flooded area, thus the new regulations were to provide flood protection. During the years 1771 - 1776, a dam was built along the right bank of the river and a new reinforced Vienna Road on top of it. In this way, the dam fulfilled both a transport function as an elevated causeway and a protective function preventing the southern inundation area from floods. ${ }^{11}$

The riverine pattern underwent other significant changes during this period. By natural development, its main flow diverged in the area around Pečňa island (Pötscheninsel) to the northern channel, where the former main channel became a tributary, the Pečňa Channel (Pečnianske rameno, or Pötschen Arm). Another transformation regarded the damming of the Croatian Channel (Carlburger Arm) left artificially cut off in 1777 as the extension of the flood protection dam. This period of arrangements also included the stabilization of the tip of the 
THREE MAIN REGULATIONS

OF THE DANUBE IN THE TERRITORY

OF TODAY'S BRATISLAVA, THE

ACTUAL AND PLANNED SHAPE OF THE RIVER

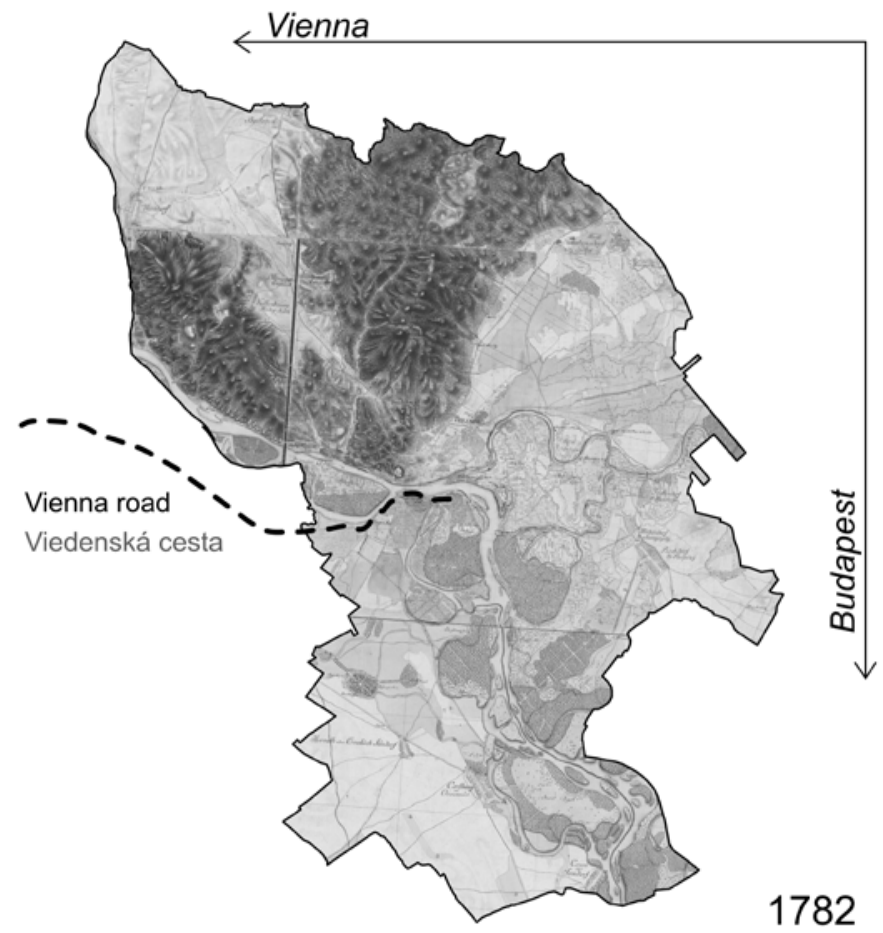

TRI HLAVNÉ REGULÁCIE DUNAJA NA ÚZEMÍ DNEŠNEJ BRATISLAVY, SKUTKOVÝ A PLÁNOVANÝ TVAR RIEKY

Author Autorka: Monika Bočková
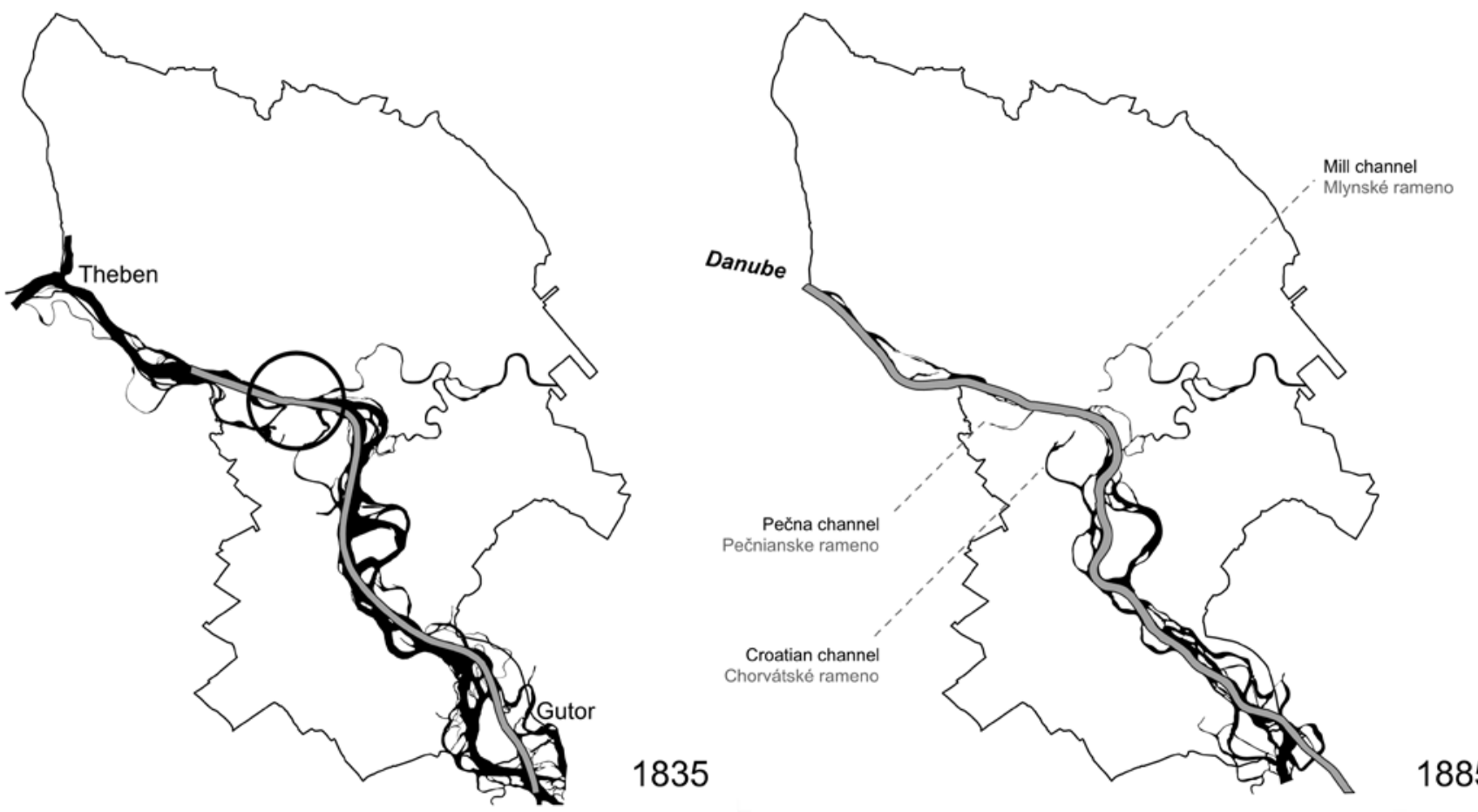


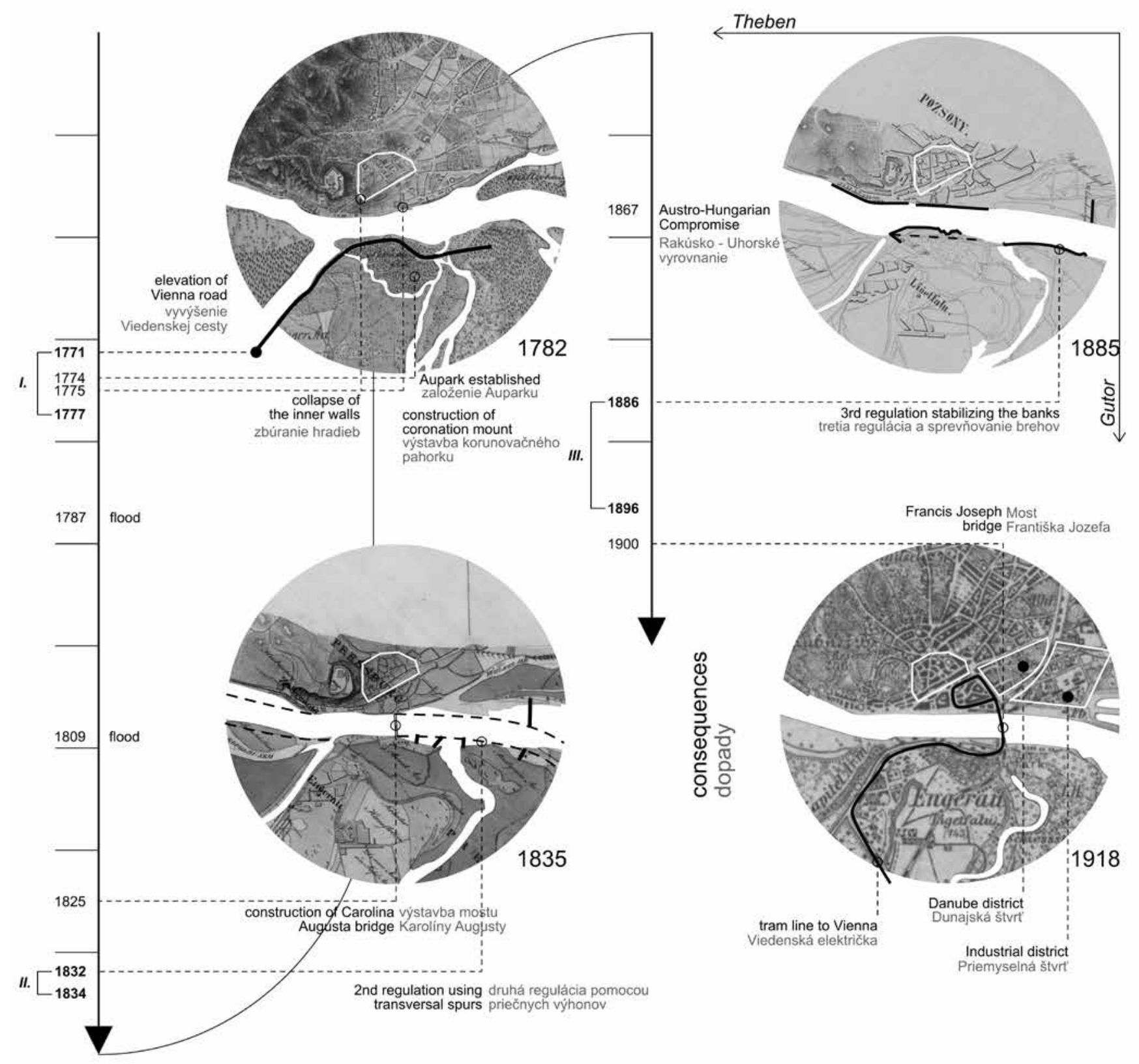

TIMELINE OF SPATIAL

INTERVENTIONS IN THE CENTRAL PART OF BRATISLAVA

ČASOVÁ OS PRIESTOROVÝCH ZÁSAHOV V CENTRÁLNEJ ČASTI BRATISLAVY

Author Autorka: Monika Bočková 
islands of the Bridge fluvial plain (Brücken $\mathrm{Au}$ ), the City fluvial plain (Stadt $\mathrm{Au}$ ) and the Middle fluvial plain (Mitterhauffen), the last one stretching between the main channel on the south and the Mill Channel (Mlynské rameno) on the north. The construction of the stone banks at its tip was the first step in eliminating the Mill Channel from the main flow. ${ }^{12}$

Traditionally, the Danube's right bank has traditionally provided Bratislava's residents with recreation, hunting and fishing, representing a natural opposite to the city on the left bank. Once this floodplain was protected by a dam, Maria Theresa initiated its formal transformation when she established a park (Aupark) open to the public in $\mathbf{1 7 7 4}$.

Although all these measures marked the beginning of a comprehensive regulation of the Danube, many of them did not last long and were destroyed by the subsequent floods. The human interventions might have even amplified the effect of flooding. An extremely destructive flood hit the city already in 1787 , causing the rupture of the right bank dam. During another flood in 1809, the side channels were reopened, including the Croatian Channel, now reconnected with the Danube after 31 years of siltation. ${ }^{13}$

The most decisive city intervention of this period was the demolition of the inner walls and the backfilling of the moat surrouding the walls in 1775 . The city was freed its medieval form and the suburbs were included into its structure. Nothing blocked the approach to the river anymore. On this occasion, recognising the impact for the potential development, Maria Theresa commissioned Franz Hillebrandt to prepare the city's first regulatory plan. In the same year, Maria Theresia also issued the construction of a new coronation mount on the left bank, to replace the earlier mount which had stood further from the river, a decision that can be regarded as the first step to the new public role of the embankment. ${ }^{14}$

The last major gesture concluding the imperial era was the construction of a pontoon bridge that connected the coronation mount with Aupark on the other side. Built in 1825 on the occasion of Caroline Augusta's coronation in Bratislava and, it was named after her, and consisted of 23 boats on which a bridge deck was laid. In case of ice jams or imminent flooding, it was dismantled and stored in safety.

A true manifestation of crucial success in the decades-long effort to modernize and improve the conditions on the Danube was the beginning of steam navigation. The first regular steamship service ran on the Danube between Vienna and Pest from 1830 onward, but the systematic regulation of this section proved to be necessary. The Helytartótanács (Lieutenancy Council) in Buda issued a decree mandating the regulation of the Danube's main bed between Devín (Theben) and Hamuliakovo (Gutor). The two-year-long regulation work started in 1832 with the aim of adjusting the riverbed to the desired shape with a continuous shoreline. For this purpose, transverse spurs were constructed along the entire section, which blocked the flow of water and gradually deprived the river of its natural meanders and branches.

\section{The Urban River}

The character of subsequent urban growth was influenced by the political events of 1867, in which the Austro-Hungarian Compromise established the dual monarchy of Austria-Hungary. The period from the Compromise to the outbreak of World War I can be considered decisive for the modernization of cities in the territory of Slovakia still as a part of the Kingdom of Hungary. ${ }^{15}$

The Hungarian government embarked on a transformation of the economic system along the path of capitalism, to emancipate the kingdom from Austrian domination. The ensuing modernization of transport, roads and street networks had a complex impact on cities. Bratislava lost its prestige but became a municipality at the county level and its image began to deviate from the traditional Austrian one. New companies were established and factories expanded, the city and its construction industry displayed lively growth. Similarly, the concentration of capital was reflected in the development of new neighborhoods in the east and southeast of the city.

In 1867 a new mayor was elected, Heinrich Justi. During his 8-years long mandate, he strongly supported the city's development and influenced its vision with numerous ambitious ideas. It was his initiative to build a representative urban waterfront and to fulfill this plan, initiated a series of city-forming decisions designed mostly by engineer Anton Sendlein. At first, he resumed the Danube regulation works on the city banks, transforming the natural riverbank into an artificial embankment. During the embankment formation, Justi ordered the demolition of the Coronation Mount and the relocation of the port outside the city center, and gradually a chain of urban spaces along the river began to emerge. ${ }^{16}$

The most innovative concept for the development of the city was presented by Justi in 1875 , including the construction of the first permanent bridge over the Danube and a water pipeline. Other deputies opposed the plan, turned down the loan and deprived Justi of his mandate. However, both of these projects later proved necessary and were eventually completed at the century's end.

The permanent bridge over the Danube in Bratislava was built in the years $1889-1890$, financed by the Hungarian state and designed by engineer Francois de Sales Cathry based in Budapest. Named after Francis Joseph I, who personally participated at its opening, it was a modern steel construction designed for road, rail and pedestrian transport, and it replaced the pontoon bridge of Caroline Augusta.

However, the construction of the permanent bridge was linked to a series of more complex arrangements. In the years 1886 - 1896, the Danube was regulated to mid-flow channelization according to plans of Enea Grazioso Lanfranconi. This Bratislava based engineer of Lombardian origins published in 1880 a work entitled On the Waterways of Central Europe and the Importance of the Regulation of the Danube River with special Consideration for the Section between Theben (Devín) - Gönyö (Gönyú) ${ }^{17}$ describing the possible modification of a section 80 kilometers long.

The core of the proposed regulation was the straightening, narrowing and fixation of the main flow. In order to achieve the river modification, a series of preparatory works had to be done, 
such as excavation works, stabilisation of important islands and cutting off all side channels. The result was the regulated modern river, with a uniform depth of 3 meters and a width of 300 meters. The minimum radius of curvature was set to $800 \mathrm{~m}$, while the individual straight sections did not exceed 7 kilometers in length. ${ }^{18}$ The fixation of the river corridor was realized through the elevation of the banks and the creation of embankment-protecting structures, with the stabilizing stonework remaining in major parts of the embankment until present days.

\section{Regulation's Consequences and Conclusion}

The changes that occurred during the examined period directly affected the subsequent urban development. The anti-flood barrier fueled the emergence of a riverside promenade. The river regulation and the stabilization of the left bank allowed the development of the Danube district, while construction of the Franz Joseph Bridge represented a step towards the city's new southward-oriented growth. The cut-off Croatian Channel was later transformed into drainage canals and the uppermost section of the cut-off Mill Channel was backfilled with soil providing the area for the first industrial quarter.

The urban history of each city includes a number of different factors. The present contribution looked at the issue from the perspective of river navigability and revealed the most crucial urban interventions that accompanied this process. The selected method brought the value of the interpretation, because even well-known historical events can reveal new connections when spatially represented.

Although the regulations of the Danube have led to the creation of an important waterway, they can also be retrospectively evaluated in terms of their negative impacts on the environment. Bratislava has lost a valuable landscape and what remains of it is subject to the pressure of urbanization. Ongoing research can therefore be a contribution to the current discussion on the future of floodplain remnants, or the possible restoration of extinct river branches.

The text was created in part thanks to the financial support of an Ernst Mach Fellowship from OeAD during a study stay at the Universität für angewandte Kunst in Vienna.

The research on the study was also made in the frame of the research project APVV-16-0584 Unintentional

City: Architectonic and Urbanistic Conceptions of the 19th and 20th

Centuries in the Urban Structure of

Bratislava.

\section{ING. ARCH. MONIKA BOČKOVÁ}

INSTITUTE OF HISTORY

AND THEORY OF ARCHITECTURE

AND MONUMENT RESTORATION

FACULTY OF ARCHITECTURE

AND DESIGN

SLOVAK TECHNICAL UNIVERSITY

IN BRATISLAVA

Námestie slobody 19

81245 Bratislava

Slovak republic

monika.bockovaO@gmail.com
1 Expression by EDGEWORTH, Matt, 2011. Fluid Pasts: Archaeology of Flow. Bristol: Bristol Classical Press.

2 Expression by CASTONGUAY, Stéphane, and EVENDEN, Matthew, 2012. Urban Rivers: Re-making Rivers, Cities and Space in Europe and North America. Pittsburgh: University of Pittsburgh Press. "We define urban rivers in a descriptive sense as rivers that flow through cities, and in an analytical sense as those rivers that have been folded into the process of urbanization, whether flowing through urban centres or not."

3 WAY, Thaïsa (ed.), 2018. River Cities, City Rivers. Cambridge, Massachusetts.

4 HOHENSINNER, Severin et al. 2019. Wasser Stadt Wien - Eine Umweltgeschichte. Vienna: Zentrum für Umweltgeschichte Wien.

5 MORAVČÍKOVÁ, Henrieta, SZALAY, Peter, HABERLANDOVÁ, Katarína, KRIŠTEKOVÁ, Laura and BOČKOVÁ, Monika, 2020. Bratislava (Un)Planned City. Bratislava: Slovart.

6 HORVÁTH, Vladimír, 1990. Bratislavský topografický lexikón. Bratislava: Tatran.

7 See more in FURTADO, M. Gonçalo C. L., 2020. The Legacy - Ignasi Solà-Morales and the contemporary urban debate. Architektúra o urbanizmus. 54(1-2), pp. $134-144$.

8 MEVISSEN, Robert, 2017. Constructing the Danube monarchy: Habsburg state-building in the long 19th century. Washington, DC: Faculty of the Graduate School of Arts and Sciences of Georgetown University.

9 Upper Section: from Passau to the Devín Gate, Middle Section: from the Devín Gate to the Iron Gate

10 HORVÁTH, Vladimír, LEHOTSKÁ, Darina and PLEVA, Ján (eds.), 1978. Dejiny Bratislavy. Bratislava: Obzor.

11 PIŠÚT, Peter, 2002. Channel Evolution of the Pre-channelized Danube River in Bratislava, Slovakia (1712 - 1886). Earth Surface Processes and Landforms. 27, pp. 369 - 390. https:// doi.org/10.1002/esp.333.

12 PIŠÚT, Peter, 2018. Využitie historických krajinomalieb na rekonštrukciu regulačných prác v koryte rieky príklad Dunaja v Bratislave. Geographia Cassoviensis. 12(2).

13 Pišút, P., 2002, pp. 369 - 390.
14 See more in ANDRÁŠIOVÁ, Katarína, DULLA, Matúš, HABERLANDOVÁ, Katarína, MORAVČÍKOVÁ, Henrieta, PASTOREKOVÁ, Laura and SZALAY, Peter, 2015. Planning the Unplanned City: Modern Urban Conceptions in a Traditional Urban Structure. Architektúra \& urbanizmus. 49(3-4), pp. $216-239$.

15 MORAVČÍKOVÁ, Henrieta, LOVRA, Éva and KRIŠTEKOVÁ, Laura, 2020. Antal Palóczi and the beginnings of modern urban planning in the Kingdom of Hungary: the example of Bratislava and Novi Sad $(1867-1918)$. Planning Perspectives. 35(2), pp. 371 381. https://doi.org/10.1080/02665433.2 020.1730937

16 Moravčíková, H., Szalay, P., Haberlandová, K., Krišteková, L. and Bočková, M., 2O2O, pp. 70 - 72.

17 LANFRANCONI, Enea G., 188o. Übe die Wasserstraßen Mittel-Europa's und die Wichtigkeit der Regulierung des Donaustromes, mit besonderer Berücksich tigung der Strecke zwischen Theben und Gönyö. Pressburg: Angermayer.

18 MÁJEKOVÁ, Jana M., 2020. Lanfranconi - the Scientist Who Changed the Shape of the Danube. In: Science without Borders: Alexander von Humboldt's Concepts in Today's World. Veliko Tarnovo: Faber Publishing House, pp. $45-51$. 